\title{
Dealing with incidents of serious disciplinary problems amongst learners: A comparative study between South Africa and selected countries
}

\begin{abstract}
Authors:
Charl C. Wolhuter ${ }^{1}$

Charles Russo ${ }^{2,3}$

Affiliations:

${ }^{1}$ School of Education,

North-West University,

Potchefstroom Campus,

South Africa

${ }^{2}$ Faculty of Education

Sciences, North-West

University, Mafikeng Campus,

South Africa

${ }^{3}$ School of Education and Allied Professions, University of Dayton, United States of America
\end{abstract}

Correspondence to: Charl Wolhuter

Email:

charl.wolhuter@nwu.ac.za

Postal address:

Private Bag X5001,

Potchefstroom 2520

South Africa

\section{Dates:}

Received: 30 Nov. 2012

Accepted: 14 June 2013

Published: 07 Nov. 2013

Republished: 21 Feb. 2014

How to cite this article: Wolhuter, C.C. \& Russo, C. 2013, 'Dealing with incidents of serious disciplinary problems amongst learners: A comparative study between South Africa and selected countries', Koers

- Bulletin for Christian

Scholarship 78(3), Art. \#451, 11 pages. http://dx.doi. org/10.4102/koers.v78i3.451

Note:

Article republished with the corrected author affiliation of Charles Russo.

\section{Copyright:}

(C) 2013. The Authors.

Licensee: AOSIS

OpenJournals. This work

is licensed under the

Creative Commons

Attribution License.

\section{Read online:}

Teachers in South African schools battle with problems in learner discipline. Research indicates that teachers are at a loss as to handling these situations. The aim of this article is to survey incidents of serious learner misconduct in a representative selection of education systems abroad to extract any guidelines that might be applicable to South African schools. Eight education systems were surveyed: Brazil, England, Turkey, Singapore, Malaysia, China, Australia and New Zealand. The international systems surveyed in this article developed promising models, namely the National Safe Schools Framework (NSSF) in Australia, the Response Early Intervention and Assessment Community Health (REACH) programme in Singapore, the National Education Plan in the state of São Paolo, Brazil, and the two models in the category of positive disciplinary approaches in New Zealand, namely the Respectful Schools: Restorative Practices in Education and the New Zealand Minister of Education's Positive Behaviour for $[a]$ Learning Action Plan. A study of these international practices and underlying principles for dealing with discipline in pedagogical situations (Christian or secular) could provide guidelines for South African teachers and education authorities.

Die hantering van gevalle van ernstige probleme met leerderdissipline in Suid-Afrikaanse skole: 'n Vergelykende studie tussen Suid-Afrika en internasionale lande. Suid-Afrikaanse skole het met probleme met leerders se dissipline te kampe. Die doel van hierdie artikel is om gevalle van ernstige probleme met leerderdissipline in 'n verteenwoordigende steekproef van buitelandse onderwysstelsels te ondersoek om riglyne vir Suid-Afrikaanse skole te vind. Agt onderwysstelsels is ondersoek: Brasilië, Engeland, Turkye, Singapoer, Maleisië, China, Australië en Nieu-Seeland. In die internasionale stelsels wat ondersoek is, is belowende modelle aangetref, naamlik die National Safe Schools Framework (NSFF) in Australië, Response Early Intervention and Assessment Community Health-program (REACH) in Singapoer, die Nasionale Onderwysplan in die staat São Paolo, Brasilië, asook twee modelle in die kategorie positiewe dissipline in Nieu-Seeland, te wete die Respectful Schools: Restorative Practices in Education en die Minister van Onderwys van Nieu-Seeland se Positive Behaviour for [a] Learning Action Plan. 'n Studie oor internasionale praktyke en die beginsels onderliggend aan die hantering van dissplineprobleme in (Christelike of sekulêre) opvoedingsituasies kan riglyne vir Suid-Afrikaanse onderwysers en onderwysowerhede verskaf.

\section{Introduction}

Recent research (De Wet 2010; Wolhuter, Oosthuizen \& Van Staden 2010; Wolhuter \& Steyn 2010) demonstrates that learner discipline, derived from the Latin discipulus, (a learner, pupil or follower) is an ongoing and serious problem in most South African schools. Whilst minor infringements, such as disruptive behaviour, ill manners and obscene language dominate, educators are not spared incidents of serious misconduct either (Wolhuter \& Van Staden 2008).

In an empirical study, surveying South African teachers, a significant percentage of the teachers interviewed indicated that they were confronted with violence on a regular basis (Wolhuter \& Van Staden 2008). The most disturbing finding of the study was that educators appeared to be at a loss about how to deal with such disciplinary problems, a situation that was confirmed by a study by the Centre for Justice and Crime Prevention. For instance, the study reported that, in 2011, more than 124000 incidents of corporal punishment were reported by learners in Gauteng (Centre for Justice and Crime Prevention 2013). This is a cause for serious concern since corporal punishment was abolished in 1996. Teachers resorting to this measure are at risk of being criminally prosecuted. The upshot is that it provides an insight into how teachers resort to measures that are essentially desperate, if not illegal, in order to maintain discipline. When facing and dealing with educational matters, international comparisons could serve as a natural 
guidance for scholars, teachers, policy-makers and the public at large (Wiseman 2012:4-5) in order to put these issues into perspective.

Comparative international perspectives serve as an accepted and time-tested method to approach problems in one's own domestic educational system (Manzon 2011:207). The aim of this article is thus to survey serious disciplinary problems with learners on a global scale. These issues are addressed in a collection of education systems abroad, and international experiences could serve as examples from which to extrapolate guidelines for South Africa. The relevance of such an exercise is enhanced by the fact that The Constitution of South Africa requires that a court, tribunal or forum must consider international law and should consider foreign law when interpreting the Bill of Human Rights (Republic of South Africa 1996, s. 31[1], [b] and [c]).

Against this backdrop, the aim of this article is to survey the handling of serious learner misconduct in selected education systems abroad to extract guidelines for the handling thereof in South African schools. The remainder of this article is divided into three sections. The first part briefly examines the method employed in this study, along with a brief discussion of Christian perspectives and why and how the eight international nations were selected for this study. The second section reviews the practices in these eight nations. The third section offers practical guidelines for educators in South Africa. The article finishes with a brief conclusion.

\section{The research method}

Reviewing the experiences of foreign education systems is an accepted practice for the evaluation of - and attempts to improve - the home education system (Manzon 2011:174-175). When attempting to improve or to reform education systems, a study of the experiences of foreign education systems, which have wrestled with the same educational problem, might reveal the full extent and implications of the problem, as well as all the causal factors. Possible solutions could thus be forthcoming (Wolhuter 2012).

When applying Education Law, it is worth recalling that systematic inquiry is a form of historical-legal research that is neither qualitative nor quantitative. In other words, Education Law is a systematic investigation involving the interpretation and explanation of the law in different school settings (Russo 2005).

Rooted in the historical nature of the law and its reliance on precedent, the study of educational law requires students to look at the past and/or other nations to locate the authority governing the disposition of questions under investigation, whether disciplinary or other. This is so because legal systems are increasingly grounded in the principle of precedent, the notion that an authoritative ruling of the highest court in a given jurisdiction is binding on lower courts. Moreover, the law, by its very nature, tends to be a reactive rather than a proactive force. It is shaped by past events, which could support stability in its application. Therefore its students need to learn to 'think outside the box' in applying the law to emerging issues such as the impact of technology on the educational process - both for good (such as virtual learning and access to information) and for ill (as in the case of cyberbullying and stalking).

This article surveys the ways serious forms of learner misconduct were handled in legally sound manners in the following eight national education systems: Brazil, England, Turkey, Singapore, Malaysia, China, Australia and New Zealand. These nations were selected primarily because they were regarded as covering the entire spectrum of the various geographical regions of the world and all the countries on the developmental continuum: from developed to developing nations. The selection includes countries of all continents: Western developed countries (England, Australia and New Zealand), newly developed countries (Singapore), emerging countries (Brazil and China) as well as countries of the South (Malaysia and Turkey). In addition, the sampling can be regarded as convenience sampling since the authors had contact with scholars who could provide sufficient detail to enable a viable comparative analysis in these well-developed systems.

\section{The Christian philosophical perspective}

For the purposes of this article, discipline refers to a willingness on the part of learners to follow the leadership or example of educators who critically apply their value systems in different situations, particularly in school contexts.

'Serious disciplinary problems' refer to infractions serious enough to be defined as acts of criminal offence. These, in turn, imply that efforts by educators to apply the three positive aspects of discipline, namely proactivity, prevention and instruction (Cloud \& Townsend 1992:178) failed and that the three less positive aspects of discipline come into play, namely: correction, chastisement and consequences.

According to the Bible, it is preferable to concentrate on the positive facets of discipline, on efforts to convince learners to emulate the actions of the educator, and to apply a value and norm system that would be socially and scripturally more acceptable.

The following may serve as biblical guidelines. On the basis of Hebrews 12:5-12 and Proverbs 13:24, educators should remind themselves that God disciplines on the basis of love. Educators, therefore, should also base discipline on love but should nevertheless be strict in their application thereof (Pr 19:18).

Children must be taught and educated to understand that, when the Spirit governs their lives, they will reap the fruits of love, happiness, peace, patience, friendliness, goodness, faithfulness, gentleness, kindness and self-control. Ephesians 6:4 teaches that educators should take care how they act towards children. Their interaction with children should not 
lead to embitterment on the part of the child; put differently, it should not lead to rebellious action.

A biblical perspective also takes into account that positive discipline might occasionally fail and that educators should be prepared to resort to the negative facets of discipline mentioned above (cf. Pr 23:13). However, as Cloud and Townsend (1992:180) state, the negative aspects of discipline should not be equated or confused with punishment. Legally, punishment is paying for breaking some or other law. Punishment as payment does not leave

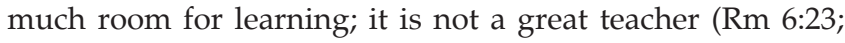
$1 \mathrm{Pt}$ 2:24). Punishment is retrospective as payment for past transgressions whilst discipline is prospective: The lessons children learn should help them not to repeat the same mistakes (Heb 12:10) or fear of any loss of relationship (Rm 8:1).

The above view of discipline is only applicable in a Christian pedagogical context. None of the education systems discussed in the following sections can be regarded as Christian. However, most of them serve secular societies lacking formal connections with religious institutions or with any religion per se and are governed by the rule of law. In such so-called secular religiously 'neutral' states, religion is relegated to the private sphere because it is regarded as intolerant and divisive and therefore dangerous to a sound civil life (Van der Walt 2007:155).

As Van der Walt (2007) observed, such societies are based on:

... an ethic of gentility and studied moderation; a code of social discourse, whereby religious beliefs and political convictions are to be expressed discreetly and tactfully, and in most cases, privately. Convictions are to be tempered by good taste and sensitivity. It is an ethic that pleads no 'offence'. (p. 203)

It must therefore be expected that the systems discussed below will attempt to conform to this secular normative system in regard to discipline and not to the biblical system outlined above.

\section{Brazil}

Article 206 of the 1988 Constitution of Brazil guarantees the right to education for everyone as a human right and the state is obliged to provide education to all (Chamber of Deputies 2010). Besides this constitutional protection, Brazil is a signatory to international treaties related to human rights and to education. The Brazilian education system is fairly decentralised.

A noteworthy approach to serious misconduct by learners has been developed in the State of São Paulo where the official policy on learner misconduct conforms to government policies designed to deter inappropriate behaviour and abuse in public schools. These documents have informed the National Education Act (Republica de Brasil 1996) and the National Education Plan (Instituto Nacional de Estudos e Pesquisas Educacionais 2001).
Article 53 of The National Education Act guarantees children the right to be respected by their educators. Under Brazilian law, people under the age of 18 lack legal capacity, and therefore, they cannot be charged with crimes. If they commit wrongs, they are subject to social-educational measures (as set out in Article 112, Republica de Brasil 1996), including the duty to repair the damages caused, perform community service, supervised freedom and suchlike, subject to due process.

Due process refers to the principle where the State, in the person of school officials, must respect the legal rights of the accused, including those stemming from the principles of natural justice. These rights include the right to a fair trial, to be considered innocent until proven guilty, the right to be heard and the right to cross-question complainants and witnesses. The National Education Act is protective rather than punitive. In order to avoid criminalising and 'judicialising' interpersonal relations, characterised by inappropriate behaviour and abuse at school, such policies encourage the representatives of all school segments to create school rules that clearly establish the rights and duties of each member of the school community and to identify which measures should be taken by school officials when the previously established and mutually-agreed-to school rules are broken.

The legal ground for Brazil's system is the general rules of conduct for schools issued by the Department of Education in 2009 (Ranieri in press), which are part of the Basic Internal Rules for State Public Schools of 1998 (Silveira 2010). These rules of conduct have the nature of general guidelines, which are not enforceable. This means that they do not consist of a code of conduct that outlines immediately the applicable penalties for each type of misconduct. The objective of the rules is to help school officials define their own rules of behaviour set out in the School Protection and Citizenship Promotion Manual with sections describing how to live together and face any weaknesses that schools may have (Silveira 2010).

The manual fills the gaps about which education professionals had long complained. It outlines the rights and duties and the responsibilities and restrictions at schools, learner punishment, lack of autonomy and the power of the principal to act independently in the event of violations as well as the expected behaviour of the learners in classrooms and even inside or outside of school buildings.

The mediator teacher program is supplemented by two others. The first program is called Prevention can be Taught, aimed at reducing learners' vulnerability in relation to the use of alcohol, tobacco and other drugs as well as preventing teenage pregnancies. The second program is known as Community Present, which encourages the discussion of subjects relating to human rights, ethics and citizenship and proposes communication actions that seek to promote non-violence and the peaceful resolution of conflicts (Ruotti, Alves \& De Oliveira 2006). 


\section{England}

In England, there is widespread concern regarding the findings of The Office for Standards in Education (Ofsted), the national government's school inspectorate, that learner conduct is no better than satisfactory in almost a fifth of England's secondary schools. The 2011 Department of Education report noted that Ofsted judged the conduct of learners in $18.4 \%$ of secondary schools as being either satisfactory or inadequate (Department of Education England [DfE] 2011). In $0.1 \%$ of secondary schools, it was judged to be inadequate, the lowest descriptor used by the inspectorate (DfE 2011:3).

The minister responsible for schools said that he was 'concerned that almost one in five secondary schools had been rated as no better than satisfactory'. In primary schools, however, the position was better: outstanding in $37.9 \%$, good in $55.8 \%$, below good in $6.2 \%$ and inadequate in just $0.1 \%$. During 2009/2010, there were 279260 cases of expulsion of learners from secondary schools and 37210 cases of expulsion of learners from primary schools (DfE 2012).

Sections 89-96 of the Education and Inspections Act of 2006 require every school to have 'a behaviour policy' (National Archives United Kingdom 2013). Schools are managed by governing bodies consisting of the head of the school, parent governors, staff governors, community governors and local authority governors. One of the important duties of governing bodies, in consultation with head teachers, is to determine 'school behaviour policies'.

Head teachers are responsible for developing and operationalising behaviour policies in the context of this framework. They must address the standards of behaviour to be expected of learners and how they are to be achieved, the school rules, disciplinary penalties for transgressing them and, equally important, the rewards for good behaviour with a view to 'securing that learners complete any tasks reasonably assigned to them in connection with their education'.

Teachers and teaching assistants as well as other staff in the school responsible for learners have the power to discipline those whose behaviour is unacceptable or who fail to follow reasonable instructions. According to the circumstances, this power could apply to behaviour outside the school as well as within it.

Staff have the power to search learners for banned items but may only do so with their consent. If a member of staff suspects that a learner has weapons, alcohol, illegal drugs or stolen items, the learner's possessions can be searched without the need to obtain consent. Teachers and other school staff are authorised to impose penalties for undesirable behaviour, and such disciplinary measures could take many forms.

Exclusion, referring to both permanent and fixed-term exclusion, can be used in cases of severe misconduct, but it is not a penalty to be exacted lightly. Because there are many negative consequences resulting from periods of exclusion, not only for the excluded individual but also for their peers, school staff and parents, guidance from the DfE encourages schools to consider alternatives to this penalty. For minor transgressions, the articulation of a teacher's disapproval or disappointment may be all that is required. For behaviour involving the use or possession of banned items, the retention or confiscation of a learner's property or, in extreme cases, the disposal of it is seen as a reasonable measure. For more serious cases of misconduct the Department for Education (DfE) guidance suggests:

- Referral: Learners remain on school rolls but are educated in another educational setting. In such cases, the learnerreferral unit that may be used includes the services of the Common Assessment Framework, the National Health Service and the Special Educational Needs providers.

- Restorative justice: In these cases, learners who have caused loss or suffering to other children are required to compensate for the loss or repair the damage they have caused.

- Mediation: It can involve parents or family members, other children and their families, residents from the community surrounding the school, local priests or imams or elders from temples, churches and mosques.

- Internal exclusion: It allows for disruptive learners to be removed temporarily, to separate them from others, to a quiet room or therapy room, where they can safely express their emotions.

- Managed move to another school: It is a voluntary process where the respective heads of schools can negotiate a move at a time or place that is in the child's best interests (Walker in press).

When learners are excluded for a fixed term, the parent has the right to challenge the head teacher's decision - either at the Governor's review meeting or via a letter to the governors, depending on the length of the exclusion. Where a learner is excluded permanently, the governors have to meet to review the exclusion - either agreeing with the head teacher's decision and upholding the exclusion or deciding that the learner should be reinstated. Where the governors uphold the exclusion, the parent or care-giver has the right to appeal to an independent panel constituted and clerked by the Local Educational Authority. The decision of independent appeals panels are binding on all parties. Still, parents or governing bodies may appeal to the High Court if they think that the decision was unlawful or that a more reasonable panel would not have arrived at that outcome.

All school staff have the power to use 'reasonable force' to restrain learners and prevent them from doing harm to themselves, other children and staff members or school (or other) property. There is special guidance on using restrictive physical interventions with children and adults who display extreme behaviour - particularly in association with learning disability or autistic spectrum disorder (DfE 2002), but corporal punishment in British state schools was banned by parliament in 1987. In private schools, however, it was not 
abolished until much later, namely in 1999 in England and Wales, in 2000 in Scotland and in 2003 in Northern Ireland.

\section{Turkey}

Turkey has risen from obscurity to prominence on the world stage due not only to the strategic location between West and East, becoming a member of North Atlantic Treaty Organisation (NATO) (1952) and an associate member of the European Community (1964), and the economic progress and political democratisation in recent years but also due to the noteworthy progress made according to the results of the Organisation of Economic Co-operation and Development (OECD) (2009) and the Programme for International Student Assessment (PISA) tests.

As to misbehaviour in schools, Turkey does not seem to have a significant problem. The PISA's 2009 results indicate that $74 \%$ of 15 -year-old learners reported calm classrooms whereas most teachers responded with 'never or hardly ever' or 'in some lessons have to wait a long time for learners to calm down' (Lozano in press). The most frequently reported misconduct in Turkish classrooms is learners speaking out of turn, interrupting other children and avoiding responsibilities (such as not doing homework or not bringing stationery, books and scripts to school).

Concerning misbehaviour towards other learners, the most frequently reported actions are verbal aggression, physical aggression, swearing and fighting. Rudeness and other forms of misbehaviour towards teachers are rare (Boyaci 2009; Danaoglu 2009; Ozben 2010; Ozkilinc \& Sabanci 2010).

Article 42 of the Constitution of Turkey stipulates that 'noone shall be deprived the right of learning and education' (Baskanlik 2010). The Basic Law of National Education, number 1739, spells out the objectives of Turkish National Education Policy (Organisation for Economic Cooperation and Development [OECD] 2007).

Corporal punishment has been banned from Turkish schools since 1923. Yet, it is deeply ingrained in Turkish culture, and it can be traced back to the Ottoman period when falaka [foot whipping] - (a practice dramatically presented visually in the popular film Midnight express) was a customary practice in the formal education system (Hatipoglu-Sumer \& Aydin 1999). It persists in Turkey today - in both homes and schools alike (Turkum 2010). In fact, it is regularly meted out at all grade levels as $50 \%-75 \%$ of children are reported to be subjected to different forms of physical punishment (Lozano in press). Moreover, the overriding majority of teachers believe it has a place in child development (Gozutuk, Er \& Karacaoglu 2006).

Regulation 27090, published in the Official Gazette of 24 December 2008, specifies the following disciplinary actions, which could be taken against learners in primary schools:

- Verbal warning: For late-coming, continual absenteeism without excuse and for displaying bad manners.

- Written censure: Arrogant or disrespectful behaviour directed towards administrators, teachers, other school staff or learners, ignoring school rules, and disrupting the learning environment, interrupting school-sponsored activities, continual lying, cheating, falsifying official records, disobeying the dress code, smoking and fighting.

- Expulsion: Actions against the fundamental principles of the Constitution, sexual assault, insulting, slandering, threatening, carrying weapons on the school premises, misusing school materials, acts of discrimination, damaging the belongings of others, attacking administrators or teachers, promoting the use of alcohol or other habit-forming substances (OECD 2008).

Similarly, with regard to secondary school learners, an official directive spells out the following disciplinary actions: written censure, short-term suspension and expulsion from formal education. However, in practice, the following methods of maintaining discipline prevail in schools in Turkey: corporal punishment, verbal approaches (which include harsh scolding as well as talking to the learner and giving verbal warnings) and sending children out of the classroom (Boyaci 2009).

Lozano (in press) concludes that teaching practices in schools in Turkey are still authoritarian and teacher-centred. These date from the Ottoman (pre-1923) years. Teachers are sensitive to any form of talking, even to whispering amongst the learners, when the teacher is teaching. The incidence of minor behavioural problems might well be a reflection of the lack of stimulating, thought-provoking learning environments in schools. Turkey's move towards being an economic power seems increasingly at odds with, and might in fact be strained by, these anarchistic methods of education. Therefore, the introduction of practical, legally sound approaches to discipline has now become imperative.

\section{Singapore}

Singapore is a small, multicultural island city-state. The population totals five million, and it consists of Malays, Chinese and Indians. Since the advent of independence in 1965, it has developed within one generation to one of the most prosperous countries in South-East Asia.

Compulsory education was introduced in 2003 but covers only the six years of primary school. Judging from the media, internet resources and informal discussions with teachers, learner misconduct appears to be a growing concern (Teh in press). Whilst the main forms of learner misconduct in the 1980s and 1990s were relatively minor in nature such as inattentiveness, poor concentration, clowning, restlessness, talking out of turn, not doing homework and failing to study for tests, Teh's (in press) interviews with principals, teachers and school counsellors have revealed that, in recent years, more serious forms of misbehaviour have started to appear. These include sexual misconduct, drug abuse and theft as well as new forms of misconduct such as cyber-bullying.

All schools in Singapore have their own school rules and regulations. The following excerpt (see Table 1) illustrates the situation in one school (Teh in press). 
TABLE 1: Offence: Absent from school or leaving the school without permission.

\begin{tabular}{lll}
\hline Number of times & Possible actions & Merit points deducted \\
\hline 1 & Inform parents or detention x 1 & 2 \\
2 & Inform parents or detention x 1 & 4 \\
3 & $\begin{array}{l}\text { Inform parents or detention x 1 } \\
\text { Counselling session } \times 1\end{array}$ & 4 \\
4 & $\begin{array}{l}\text { Inform parents or detention x 1 } \\
\text { Counselling session x1 } \\
\text { Caning }\end{array}$ & 4 \\
\hline
\end{tabular}

Singaporean politics are dominated by the People's Action Party, which has been ruling without interruption since independence. This party, especially its founder-leader, Yew Kuan Lee, has made it clear that the Western model of human rights and democracy is not appropriate for Singapore and that every nation should be allowed to develop its own forms of human rights on its own cultural base (Gopinathan 2001:6).

Inspired by Confucian philosophy, the style of government has been authoritarian, inflexible and paternalistic with freedom of expression, assembly and association limited unashamedly (Lee 1994). Due process is therefore not prescribed for school actions. The belief is that once school rules are broken, school authorities have the prerogative to impose punishment (Teh in press). Common methods used by schools to maintain discipline include:

- counselling by school counsellors or educational psychologists

- reflection whereby learners are made to write down what they did wrong and why it is wrong

- punitive measures such as demerit points, which may result in the deprivation of school awards

- disqualification from representing the school in competitions

- suspensions (rare)

- expulsions (rare)

- caning (rare) (see Teh in press).

Corporal punishment is lawful although the Ministry of Education has given strict guidelines on the application thereof.

A tool that is available for schools for dealing with learners with behavioural problems is the Response, Early intervention and Assessment in Community Health programme. Under this programme, school counsellors obtain the help of a multi-disciplinary team consisting of medical doctors, clinical psychologists, counsellors, social workers, occupational therapists, nurses and administrators. The team helps school counsellors to provide suitable school-based interventions to help these learners (Institute of Mental Health 2011). As many instances of misconduct are due to learners suffering from severe emotional and behavioural problems, school counsellors have this resource to provide suitable schoolbased interventions to help the affected learners (Teh in press). There is thus a discernible trend towards counselling, parental involvement and community interventions with punishment being relegated to the last resort (ibid:in press).

\section{Malaysia}

The high rate of population growth in Malaysia resulted in a high learner-teacher ratio which, in turn, makes the maintenance of discipline more difficult. As in many countries, Malaysia experiences a gradual increase in the number of cases of student misconduct (Tie in press). For example, in 1999, as a response to public demand for safer schools, the Educational Planning and Policy Research Division of the Ministry of Education conducted a study on gang activities in Malaysian schools (Malaysia Ministry of Education, Educational Planning and Policy Research Division 1999). Very recently, cyber-bullying has reared its ugly head.

The bases of the legal system in Malaysia are the Constitution and English Common Law. The latter has been retained since independence on 31 August 1957. Key constitutional principles also have a bearing on the school law and student discipline in particular:

- equality before the law and equal protection by the law

- the right to receive education

- the freedom to profess, practise and propagate religion

- freedom of speech and expression (Malaysia 2010).

Most litigation on learner discipline focused on fundamental liberties (Tie in press). Also relevant is the Education Act of 1996 (Malaysia 1996). The stipulation of this act is that learners have the right to study in an environment that is safe from physical and emotional threats. Finally, the Ministry of Education issues from time to time procedural and administrative guidelines related to school management and governance.

According to the common law doctrine of in loco parentis, literally, 'in the place of the parent', educators are required to ensure that learners are safe whilst at school. Educators are thus accorded the power to maintain discipline to protect learners from being the victims of misconduct and at the same time to create an environment that is safe - for teaching and learning activities to take place.

The Ministry of Education disseminates a comprehensive set of school rules and regulations. Schools provide learners with a copy of the school rules and regulations (Tie in press). School rules are enforced by means of a system of surveillance, penalties and punishments, which include demerit points, corporal punishment, alternative school placement, suspension and expulsion (Tie in press). Corporal punishment is allowed although the Ministry of Education has issued a clear set of guidelines regarding the application of corporal punishment. Following a court ruling, suspension and expulsion can only be imposed for serious misconduct such as the possession of a weapon, drug abuse and participation in crime, and only after due process.

\section{China}

In traditional Confucian culture, the teacher-learner relationship is prescribed as the learner being absolutely obedient to the teacher - and following his and her commands to the last detail. When China entered a time of rapid change and societal transformation and modernisation 
in the late 1970s, the Confucian moral structure upon which the society had been built became loose and more relaxed. This meant, amongst other things, that disciplinary problems with learners also continued to exist in China. One survey reported that $45 \%$ of primary school teachers were of the view that they spent too much time on learners' behavioural problems (Shen 2009). Whilst the most frequent problem is not paying attention (Ding 2008), more serious forms of misconduct also occur such as vandalism, substance abuse, intimidation, harassment of other learners, fighting and theft (Shen, Xianchen \& Hiroshi 2000).

A new system of maintaining learner discipline is taking shape based on the constitution, statutes and regulations by the State Council and the Ministry of Education. The main acts containing provisions with regard to learner discipline are the Education Act (1995) (China Education Center [CEC] 2013a), the Teacher Law (1993) (CEC 2013b) and the Compulsory Education Law (2006) (CEC 2013c). Still retaining a quite centralised political system, schools in China are not the official sources of law.

Shen, Wang and Zhang (in press) distinguish between two main categories of methods employed to maintain discipline in Chinese schools: formal sanctions by officials (chufen) and informal discipline by the teachers (chengjie). Formal sanctions are used in cases of severe forms of misconduct, and these methods stem from state laws. Informal methods are devised by teachers and are used on a daily basis for relatively minor infractions. Except for a clear ban on corporal punishment, the laws are largely silent on the legal status of these informal disciplinary methods.

The Education Law (1995) grants schools the authority to impose sanctions on learners who make themselves guilty of misconduct (CEC 2013d). The act does not spell out specific sanctions, but these can be found in various Ministry of Education regulations. Such sanctions include (Shen et al. in press):

- warning (jingga)

- severe warning (yanzhong, jinggao)

- documentation of violence (jiguo)

- probation (liuxiao chakan)

- involuntary withdrawal from school (leling tuixue)

- expulsion (kaichu xueji).

Chinese law is silent on the powers of teachers in disciplining learners even though they use a variety of means including verbal reprimands, confiscations, detentions, requiring a learner to hand-copy a text, calling a teacher-learner conference, time out of the classroom as well as physical labour. Physical labour may take the form of learners being ordered to clean classrooms, run on playgrounds or copy their homework by hand a number of times (Shen et al. in press).

Due process in schools is relatively new in China, dating only from 1999 in the court ruling of Tien Yong versus the Beijing University of Science and Technology (Shen et al. in press). Due process measures include provisions regarding the learners' right to defend themselves, the requirement of giving notice to parents and the right to appeal (Shen et al. in press).

\section{Australia}

In Australia, the power of education is vested in the six states and the two self-governing territories making up the federal state. Each state has its own ministry of education. The powers and functions of the ministers of education and their ministries are set out in educational legislation and are usually broad to include, for example, the establishing, maintaining and closing of schools and education services, the allocation of resources, controlling discipline, establishing guidelines for codes of conduct and approving programmes of instruction. At school level, principals are responsible for the day-to-day management of schools. All schools have school councils although their powers differ considerably from one state to the next.

The framing and implementation of educational law and policy are underpinned by guiding principles that advocate and support a proactive, positive and educative approach to discipline and the management of behaviour and that give effect to children's fundamental rights and freedoms such as the right to learn in a safe environment that is free from disruption, intimidation, harassment and discrimination (Squelch in press).

For example, the policy of the state of New South Wales on discipline states: 'All students and staff have a right to be treated fairly and with dignity in an environment free from disruption, intimidation, harassment, victimization and discrimination' (New South Wales Department of Education and Training 2011). This is also the underlying philosophy explicitly stated in the National Safe Schools Framework (NSSF) which was launched in 2003 - with the aim of providing a set of common principles for establishing safe and supportive school environments (Education Services Australia 2003).

Education legislation typically states that one of the functions of teachers is to supervise learners and to maintain proper order and discipline (Squelch in press). Teachers may use a variety of approaches and strategies to manage learners' behaviour in accordance with legislation, administrative guidelines and school policy (Squelch in press). Corporal punishment is prohibited in all schools except in the Northern Territory. The methods of maintaining discipline include detention, time-out, school and community service, suspension and expulsion.

The authority to suspend or expel learners varies from jurisdiction to jurisdiction. In some states, such as the state of Victoria, principals may do so only on the basis of orders from the Minister of Education. In others, such as South Australia or Queensland, the school principal is empowered to suspend or to expel a learner (Squelch in press). 
Procedures for dealing with suspension and expulsion are found in legislation, education regulations and departmental guidelines. The fundamental principle of natural justice, essentially the right to be heard and the right to fair and impartial decisions, underpins these procedures (Squelch in press). Both parents and learners should receive proper prior notification of such hearings.

In general, natural justice must be followed before decisions are made to suspend or to expel learners. The practice has now been established that, in cases of serious misconduct, immediate suspension orders can be issued. This is appropriate in cases of criminal behaviour and/or where learner's (mis)behaviour places the health, wellbeing and safety of themselves and others at serious risk.

\section{New Zealand}

A major reform occurred in New Zealand education when a Labour Party government took over in 1987 and launched an education restructuring programme based on the principles of neo-liberal economics. This reform was known as 'Tomorrow's schools: The reform of education administration in New Zealand', and it was put into legislative form by the Education Act of 1989 (Parliamentary Counsel Service New Zealand 2013a). The administration of all schools devolved from central government to individual schools. Every school was henceforth to be administered by a locally elected board of trustees.

All teachers must register with the Teachers' Council, and the Code of Ethics places a legal obligation on them to 'promote the physical, emotional, social, intellectual and spiritual wellbeing of learners' (Varnham in press). The right to education is stipulated in s. 3 of the Education Act of 1989 (Parliamentary Counsel Service New Zealand 2013a).

Educational authorities place a strong responsibility on teachers and schools with respect to the creation and maintenance of environments that are safe and conducive to learning for learners. Section 60A of the Education Act requires teachers or school officials to report to parents any matters that may put a learner at risk of not achieving or slowing a learner's progress or harming a learner's relationships with teachers or with other learners (Parliamentary Counsel Service New Zealand 2013a).

Principals must ensure that learners receive all the help they need to change their behaviour. Parents are to be involved in dealing with behavioural problems. The law also entrusts the School Board of Trustees with the duty to ensure the safety of students. New Zealand is also a signatory to the United Nations Convention on the Rights of the Child. This affirms the right to protection from violence (Article 19), a right to education that develops respect for children's human rights, identity and democracy (Article 28) and a right for education to be delivered in a spirit of peace (United Nations Office of the High Commissioner for Human Rights 2013, Article 29).
New Zealand enacted a Bill of Rights Act in 1990 that includes the right not to be subjected to disproportionately severe treatment or punishment (Parliamentary Counsel Service New Zeland 2013b, s. 9) and protection against unreasonable search and seizure (ibid:Article 21). However, after some incidents of violent student behaviour and weapons on school premises, the Minister of Education stated in 2011 that these rights can be overruled by the principle that schools should be physically and emotionally safe environments for learners if educators suspect that a learner is in possession of items which poses an immediate or direct threat to their own safety or the safety of others (Varnham in press). In such instances, officials may confiscate items and, if necessary, conduct a search (ibid:in press).

The Education Act of 1989 addresses suspensions and expulsions in cases of gross misconduct or when continual disobedience is considered harmful or a dangerous example to other learners at the school. A history of little success of traditional (reactive, retributive) methods of maintaining discipline in New Zealand schools has led to a shift to more restorative approaches (Varnham 2005). The Ministry of Education has posted guidelines for behaviour management on its website. The website underscores the principle that school culture strongly influences the state of learner behaviour and guides schools to consider a range of proactive strategies in this regard.

\section{South Africa}

South African education is being plagued by incidents of serious learner misconduct. The legal framework for the handling of learner misconduct in South Africa is the Constitution with its Bill of Human Rights, the South African Schools Act and regulations issued by the Minister of Basic Education. The Bill of Human Rights is based on the values of freedom, equality and dignity (Republic of South Africa 1996) and is widely hailed as one of the most progressive in the world. This has a direct bearing on the handling of student misconduct in schools, as does the following Rights specified in the Bill:

- the right to freedom and security of the person

- freedom of religion, belief and opinion

- freedom of expression

- freedom of association (Republic of South Africa 1996:8).

Other relevant sections are s. 28(2), which rules that: 'The best interest of the child is of paramount importance in every matter concerning the child.' Also relevant is s. 29(1)(a), which guarantees the right to basic education; and Section 33, which specifies that everyone has the right to administrative action that is lawful, reasonable and administratively fair (Republic of South Africa 1996).

Whilst the South African Schools Act 1996 directs school governing bodies to draw up a code of conduct for learners and to take action against those learners transgressing these, the constitutionally protected rights make it very difficult to act against culprits. Furthermore, Smit and Rossouw 
(in press) also marshal the evidence of a long list of cases, showing that heads of provincial Education Departments are very reluctant to confirm the expulsion of learners found guilty of serious misconduct (in terms of South African law, heads of provincial Education Departments have the final say when it comes to the expulsion of learners; school-governing bodies can only recommend expulsion).

South African teachers have relied heavy on corporal punishment. In the post-1994 political context, this practice has become especially controversial as the contention amongst progressive analysts and historians of education is that corporal punishment had been applied in (the pre-1994) Black schools more frequently and severely than in the White schools and was an instrument to 'beat Black children into submission' (Christie 1991).

Both the 1996 South African Schools Act and a 2000 Constitutional Court Ruling have now prohibited corporal punishment even in private schools (Smit \& Rossouw in press). The Constitutional Court found corporal punishment to be a cruel and degrading form of punishment that violates a person's dignity and consequently declared it illegal (ibid:in press). Research has found that teachers in South Africa do not have in their repertoire methods of maintaining discipline which, in their experience, are effective.

Schools that use detention, a point-demerit system, extra work, community service, the final measures of suspension and expulsion and corporal punishment (for the $15 \%$ of South African teachers who, according to research, still use it) (Wolhuter \& Van Staden 2008) are not only ineffective. They also use retroactive methods that are of a retributive nature. Educationally preventive methods are decidedly preferable (cf. Oosthuizen, Wolhuter \& Du Toit 2003), especially methods of a restorative instead of a retributive nature and based on a positive perspective towards discipline (cf. Van der Walt, Potgieter \& Wolhuter 2010). After an empirical study on learner discipline in schools, Eloff, Oosthuizen and Van Staden (2010) came to the conclusion that a whole-school approach should be rolled out when addressing the problem of disciplinary problems with learners in South African schools.

\section{Analysis and discussion}

South African teachers and school officials appear to be at a loss as to how to maintain discipline, especially with instances of serious learner misconduct. Whilst some might argue that they were rendered rudderless after the power to apply corporal punishment was taken away, in terms of the law, the drastic options of suspension and expulsion still exist. However, the political-administrative structures above schools have proved time and again their reluctance to support schools in such acts. There are, in fact, examples of frustrating schools' attempts to suspend or expel learners guilty of serious misconduct.

From the international comparative survey, it has transpired that, in countries such as Australia and New Zealand where modern-day human rights conventions are applied, provision exists for the immediate suspension of learners reasonably suspected of having committed serious transgressions. It is recommended that policy-makers, educational authorities and courts consider these international precedents. Further, as Eloff et al. (2010) recommended, whole-school approaches and pro-active strategies should be considered.

In the international experience surveyed in this article, promising models exist, all of a restorative nature, namely: the National Safe Schools Framework (NSSF) in Australia, the REACH programme in Singapore, the National Education Plan in the State of São Paolo, Brazil and New Zealand's two models in the category of positive discipline approaches, namely the approaches contained in the 'Respectful Schools: Restorative Practices in Education' and the Minister of Education's 'Positive Behaviour for Learning Action Plan'. South African teachers, schools and educational authorities could fruitfully look to these for guidance.

In the light of the preceding analysis, educational leaders and lawyers in South Africa should consider the following suggestions when devising policies for learner discipline.

Firstly, leaders should ensure that teams charged with developing policies involve representatives of key constituencies, both when they are initially developed and when they are revised - because ensuring cooperation is of paramount importance. Policy-writing teams should include members of governing bodies, a school lawyer, administrators, teachers, staff, parents and learners, particularly at the upper levels since these policies would impact their activities.

Secondly, such policies must include clear, precise definitions of prohibited behaviour such as bullying, intimidation, harassment and other unacceptable behaviour. Since policies mandating punishment for such offenses as acting or saying something 'mean' or 'hurtful' can easily be invalidated as vague or over-broad, terms must be as precise as possible so that they can survive challenges and help to ensure school safety. Policies should add that off-campus behaviour could also be punishable if they create hostile environments for victims, infringe on their rights or create material and substantial disruptions to the educational process.

Thirdly, such policies should include physical, verbal, written and electronic forms of misbehaviour that might lead to physical acts of violence or gestures causing physical or emotional harm, damage to victims' property, place victims in fear of harm, create hostile environments and/or infringe on the rights of others.

Fourthly, policies should prohibit misbehaviour based on race, ethnicity, national origin, socio-economic status, religion, gender, sexual orientation (actual or perceived) and/or disabilities. 
Fifthly, policies should protect victims from ridicule once they have filed complaints since learners have committed suicide in response to being subjected to even more abuse from peers after having reported incidents to educators (Bernstein-Klomek, Sourander \& Gould 2010).

Sixthly, policies must include substantive and procedural due-process protection that:

- Require learners and staff to report instances of disciplinary infractions to designated school officials as soon as reasonably possible after they have occurred, such as the end of the school day.

- Set time-frames within which administrators must complete investigations, typically ten school days, determining that educators may face liability for deliberate indifference by failing to respond to and investigate incidents.

- Protect the due-process rights of the accused since allegations are just that - unless or until they are substantiated, and as such, policies should set deadlines by which time disciplinary processes must be completed, penalties imposed and appeals filed and resolved whilst proceedings must be kept confidential.

- Specify a range of penalties for first, second and repeat offenders from short-term suspensions to expulsions, adding that learners can receive significant sanctions even on their first offenses - if their actions warrant such discipline.

- Mandate the reporting of incidents to law-enforcement authorities if there is evidence that learners might have committed crimes.

Seventhly, policies should be included in student and faculty handbooks. Also, learners and parents should be required to acknowledge in writing that they have read, understood and agree to abide by these provisions in the handbooks.

Eighthly, leaders should provide annual professional development opportunities for dealing with disciplinary problems for teachers and staff.

Ninthly, leaders should offer programmes for parents to help them better understand and respond to situations in which their children have either misbehaved or been harmed - due to the actions of their peers.

Tenthly, leaders should offer counselling to victims and their families to help overcome the effects of being harmed by school violence.

Eleventhly, leaders should develop peer-intervention programmes to help learners deal with misbehaviour and violence in their lives.

Twelfthly, teams should review their policies annually and not during or immediately after controversies to ensure that they are up-to-date with advances in the law, research and world- and life-view developments in the societies where they serve.

\section{Conclusion}

It is a sad reality of school life that learners misbehave with the consequence that their actions often harm peers. Educators and lawyers can learn from other nations. They can identify guidelines for dealing with similar cases, weighing them against the norm and value system prevalent in the societies where they serve. This might help to make schools safe places where learning can actually occur.

\section{Acknowledgements Competing interests}

The authors declare that they have no financial or personal relationship(s) that may have inappropriately influenced them in writing this article.

\section{Authors' contributions}

Both authors of this article C.C.W. (North-West University) and C.R. (University of Dayton and North-West University) contributed equally to the writing thereof.

\section{References}

Baskanlik, T.C., 2010, 'The constitution of the Republic of Turkey', in Office of the Prime Minister, Directorate General of press and information, viewed n.d., from http:// www.byegm.gov.tr/content.aspx?s=tcotrot

Bernstein-Klomek, A., Sourander, A. \& Gould, M., 2010, 'The association between bullying and suicide in childhood to young adulthood: A review of cross-sectional and longitudinal research findings', Canadian Journal of Psychiatry 55(5), 282-288.

Boyaci, A., 2009, 'Comparative investigation of elementary school students' opinions towards corporal punishment from aspects of several variables', World Applied Sciences Journal 6(7), 933-938.

Centre for Justice and Crime Prevention, 2013, National school violence study, viewed 18 April 2013, from http://cjcp.skinthecat.co.za/articlesPDF/65/Monograph12School-violence-in-South\%20Africa.pdf

Chamber of Deputies, 2010, Constitution of the Federative Republic of Brazil, Documentation and Information Center, Publishing Coordination, Brasilia.

China Education Center (CEC), 2013a, Basic education law in China, viewed n.d., from http://www.chinaeducenter.com/en/edulaw.php

China Education Center (CEC), 2013b, Teachers law in China, viewed n.d., from http:// www.chinaeducenter.com/en/cedu/tlc.php

China Education Center (CEC), 2013c, Compulsory education law of China, viewed n.d., from http://www.chinaeducenter.com/en/cedu/cel.php

China Education Center (CEC), 2013d, Basic education law in China, viewed n.d., from http://www.chinaeducenter.com/en/edulaw.php

Christie, P., 1991, The right to learn: The struggle for education in South Africa, Ravan, Braamfontein.

Cloud, H. \& Townsend, J., 1992, Boundaries, Zondervan, Grand Rapids.

Danaoglu, G., 2009, 'Student misbehaviours and investigating tackling strategies of primary teachers and branch teachers in fifth classes of primary education', MA thesis, Faculty of Education, Cukurova University.

Department of Education and Science, England, 2002, Guidance on the use of physical interventions for staff working with children and adults who display extreme behaviour in association with learning disability and/or autistic spectrum disorders, viewed n.d., from http://dera.ioe.ac.uk/15434/1/guidance $\% 20$ on\%20 the\%20use\%20of\%20restrictive\%20physical\%20interventions.pdf

Department of Education England (DfE), 2011, Ensuring good behaviour in schools: A summary for heads, governing bodies, teachers, parents and pupils, Her Majesty's Stationary Office, London.

Department of Education England (DfE), 2012, School exclusion statistics 2009/2010, viewed 20 June 2012, from http://www.education.gov.uk

De Wet, C., 2010, 'School principals' experience and observation of educator-targeted bullying', Tydskrif vir Christelike Wetenskap 46(1), 187-209.

Ding, M., 2008, 'Chinese teachers' perceptions of students' classroom misbehavior', Educational Psychology 28, 305-324.

Education Services Australia, 2003, National safe schools framework, viewed 05 August 2012, from http://www.mceetya.edu.au/verve/_resources/natsafeschools_file. pdf

Eloff, C.H., Oosthuizen, I.J. \& Van Staden, J.G., 2010, 'An educator approach towards learner discipline as a pre-requisite in dealing with learner misconduct', Tydskrif vir Christelike Wetenskap 46(1), 125-144. 
Gopinathan, S., 2001, 'Globalisation, the state and education policy in Singapore', in J.O. Tan, J. Opinathan \& W.K. Hok (eds.), Challenges facing the Singapore education system today, pp. 3-17, Prentice Hall, Englewood Cliffs, NJ.

Gozutuk, D., Er, O. \& Karacaoglu, C., 2006, 'Corporal punishment at school', paper presented at the International Symposium of Violence and Schools, Istanbul, Turkey, 28-31 March.

Hatipoglu-Sumer, Z. \& Aydin, G., 1999, 'Incidence of violence in Turkish schools: A review', International Journal for the Advancement of Counselling 21, 335-347.

Institute of Mental Health, 2011, Singapore: Response early assessment and intervention in community health program (REACH), viewed n.d., from www. aamh.edu.au/_data/assets/pdf_file/.../Singapore_pp79-84.pdf

Instituto Nacional de Estudos e Pesquisas Educacionais, 2001, National education plan of Brazil, viewed n.d., from http://planipolis.iiep.unesco.org/upload/Brazil/ Brazil\%20National\%20Education\%20Plan\%20.pdf

Lee, K.Y., 1994, 'Confucian values helped Singapore prosper', The Straits Times, 06 October, p. 6.

Lozano, R., (in press), 'Best practices for the management of student misconduct in Turkey', in C.J. Russo, I.J.O. Oosthuizen \& C.C. Wolhuter (eds.), Best practices for student misconduct on six continents, Littlefield and Rowman, New York.

Malaysia, 1996, Education Act 1996 (Act 550), International Law Book Services, Kuala Lumpur.

Malaysia, 2010, Federal constitution, International Law Book Services, Kuala Lumpur.

Malaysia Ministry of Education, Educational Planning and Policy Research Division, 1999 , Study of gangsterism in daily secondary schools, Ministry of Education, Kuala Lumpur.

Manzon, M., 2011, Comparative education: The construction of a field, Comparative Education Research Centre, The University of Hong Kong, Hong Kong.

National Archives United Kingdom, 2013, Education and Inspections Act, viewed n.d., from http://www.legislation.gov.uk/ukpga/2006/40/contents

New South Wales Department of Education and Training, 2011, Student discipline in government schools Policy, viewed n.d., from http://www.det.nsw.edu.au/dept/ legislation/discipline

Oosthuizen, I.J., Wolhuter, C.C. \& Du Toit, P., 2003, 'Voorkomende of bestraffende maatreëls in Suid-Afrikaanse skole: Watter benadering moet voorkeur geniet? [Preventive or punitive disciplinary measures in South African schools: Which should be favoured?]', Koers - Bulletin for Christian Scholarship 68(4), 457-479. http://dx.doi.org/10.4102/koers.v68i4.352

Organisation for Economic Cooperation and Development (OECD), 2007, Basic education in Turkey, viewed n.d., from http://www.oecd.org/education/ school/39642601.pdf

Organisation for Economic Cooperation and Development (OECD), 2008, Reviews of national policies for education: Basic education in Turkey background report viewed n.d., from http://www.oecd.org/dataoecd/8/51/39642601.pdf

Organisation for Economic Cooperation and Development (OECD), 2009, OECD PISA Rankings, viewed n.d., from http://www.oecd.org/pisa/46643496.pdf

Ozben, S. 2010, 'Teachers' strategies to cope with student misbehaviour', Procedia Social and Behavioural Sciences 2, 587-594.

Ozkilinc, N.G. \& Sabanci, A., 2010, 'Views on school managers about primary schoo students' misbehaviours and their strategies to cope with these', Pamukkale University Journal of Education Faculty II, 41-53.

Parliamentary Counsel Service New Zealand, 2013a, Education Act, Act 80 of 1989 viewed n.d., from http://www.legislation.govt.nz/act/public/1989/0080/latest/ DLM175959.html

Parliamentary Counsel Service New Zealand, 2013b, Bill of Human Rights Act, Act 109 of 1990, viewed n.d., from http://www.legislation.govt.nz/act/public/1990/0109/ latest/DLM224792.html

Ranieri, N., (in press), 'Bringing peace to schools: The experience in the Basic Education Network in the State of São Paolo, Brazil', in C.J. Russo, I.J.O. Oosthuizen \& C.C. Wolhuter (eds.), Best practices for student misconduct on six continents, Littlefield and Rowman, New York.

Republica de Brasil, 1996, Lei 9394/1996, viewed n.d., from www.planalto.gov.br/ ccivil_03/leis/19394.htm

Republic of South Africa, 1996, The Constitution of the Republic of South Africa, Act 108 of 1996, Government Printer, Pretoria.

Ruotti, C., Alves, R. \& De Oliveira, V., 2006, Cubas in Violência na Escola: Um Guia para Pais e Professores, 1st edn., Imprensa Oficial, São Paulo.
Russo, C.J., 2005, 'Legal research: An emerging paradigm for inquiry', Perspectives in Education 23(1), 41-51.

Shen, J., 2009, 'Chinese elementary school teachers' perceptions of students' classroom behavioural problems', Educational Psychology 29, 187-201.

Shen, J., Xianchen, L. \& Hiroshi, K., 2000, 'Behavioural and emotional problems in Chinese children: Teacher reports for ages 6 to 11', Journal of Child Psychology \& Psychiatry \& Allied Disciplines 41, 101-116.

Shen, S., Wang, J. \& Zhang, R., (in press), 'Student misconduct in Chinese schools: A legal and educational analysis', in C.J. Russo, I.J. Oosthuizen \& C.C. Wolhute (eds.), Best practices for student misconduct on six continents, Littlefield and Rowman, New York.

Silveira, A.A.D., 2010, 'O Direito à Educação de Crianças e Adolescentes: Análise da atuação do Tribunal de Justiça de São Paulo (1991-2008)', PhD dissertation, School of Education, University of São Paulo.

Smit, M. \& Rossouw, J.P., (in press), 'Student discipline in South Africa', in C.J. Russo, I.J Oosthuizen \& C.C. Wolhuter (eds.), Best practices for student misconduct on six continents, Littlefield and Rowman, New York.

Squelch, J., (in press), 'Australia', in C.J. Russo, I.J.O. Oosthuizen \& C.C. Wolhuter (eds.), Best practices for student misconduct on six continents, Littlefield and Rowman, New York.

Teh, M.K., (in press), 'Best practices for student misconduct on six continents: Singapore', in C.J. Russo, I.J. Oosthuizen \& CC Wolhuter (eds.), Best practices for student misconduct on six continents, Littlefield and Roman, New York.

Tie, F.H., (in press), 'Best practices for the management of student misconduct in Malaysia', in C.J. Russo, I.J.O. Oosthuizen \& C.C. Wolhuter (eds.), Best practices for student misconduct on six continents, Littlefield and Rowman, New York.

Turkum, A.S., 2010, 'Stance against violence in schools: School staff's ethical roles in the wellbeing of students in Turkey, Cultura, International Journal of Philosophy of Culture and Axiology VII(2), 164-170.

United Nations Office of the High Commissioner for Human Rights, 2013, United Nations convention on the rights of the child, viewed n.d., from http://www. ohchr.org/en/professionalinterest/pages/crc.aspx

Van der Walt, B.J., 2007, Transforming power: Challenging contemporary secula society, Institute for Contemporary Christianity in Africa, Potchefstroom.

Van der Walt, J.L., Potgieter, F.J. \& Wolhuter, C.C., 2010, 'Positiewe dissipline in die hande van die opvoeder [Positive discipline in the hands of the teacher]', Tydskrif vir Christelike Wetenskap 46(1), 145-168.

Varnham, S., 2005, 'Seeing things differently: Restorative justice and schoo discipline', Education and Law 17(3), 87-101.

Varnham, S., (in press), 'Best practices for student misconduct on six continents: New Zealand', in C.J. Russo, I.J.O. Oosthuizen \& C.C. Wolhuter (eds.), Best practices for student misconduct on six continents, Littlefield and Rowman, New York.

Walker, P., (in press), 'Student misconduct in the United Kingdom', in C.J. Russo, I.J.O. Oosthuizen \& C.C. Wolhuter (eds.), Best practices for student misconduct on six continents, Littlefield and Rowman, New York.

Wiseman, A., 2012, 'A framework for understanding international perspectives in education', in N.P. Popov, C. Wolhuter, B. Leutwyler, G. Hilton, J. Ogunleye \& P.A. Almeida (eds.), International perspectives on education, pp. 1-21, Bulgarian Comparative Education Society, Sophia.

Wolhuter, C.C., 2012, 'Godsdiens in onderwys in Suid-Afrika: Beligting vanuit internasionaal-vergelykende perspektiewe [Religion in education in South Africa: Enlightenment from internationally comparative perspectives]', Tydskrif vir Christelike Wetenskap 48(1/2), 171-201.

Wolhuter, C.C., Oosthuizen, I. J. \& Van Staden, J.G., 2010, 'Skoolfase/ leerderouderdom as faktor in Suid-Afrikaanse skole [School phase/student age as a factor in South African schools], Tydskrif vir Christelike Wetenskap 46(1), 169-186.

Wolhuter, C.C. \& Steyn, H.J., 2010, 'Eerstejaarstudente se belewing van leerderdissipline in Suid-Afrikaanse skole [First-year students' perception of student discipline in South African schools]', Tydskrif vir Christelike Wetenskap $46(1), 211-226$.

Wolhuter, C.C. \& Van Staden, J.G., 2008, 'Bestaan daar 'n dissiplinekrisis binne SuidAfrikaanse skole? Belewenis van opvoeders [Is there a discipline crisis in South African schools? Experience of educators]', Tydskrif vir Geesteswetenskappe 48(3), 389-398. 